Інноватика у вихованні. Випуск 12. 2020.

\author{
УДК 373.2:613/614:004
}

DOI: $\underline{10.35619 / \text { iiu.v1i12.314 }}$

\author{
Потапчук Тетяна \\ доктор педагогічних наук, професор, \\ професор кафедри теорії та методики \\ дошкільної і спеціальної освіти ДВНЗ \\ «Прикарпатський національний університет \\ імені Василя Стефаника», \\ м. Івано-Франківськ, Україна \\ ORCID: 0000-0003-1680-6976 \\ e-mail:tatvolod@ukr.net
}

\title{
ПРОФЕСІЙНО-ПЕДАГОГІЧНА ПІДГОТОВКА МАЙБУТНЬОГО ПЕДАГОГА ПОЧАТКОВИХ КЛАСІВ ДО ВИКОРИСТАННЯ ЗДОРОВ'ЯЗБЕРЕЖУВАЛЬНИХ ТЕХНОЛОГІЙ
}

\begin{abstract}
Анотація. У статті зазначено, що загальним благом суспільства $є$ турбота про людину, уміння любити ближнього, а головною цінністю суспільства життя і здоров'я людини. Стан здоров'я населення $є$ важливим показником розвитку суспільства, тому турботі про здоров'я людини, мотивації іiі на здоровий спосіб життя приділяється велика увага в усьому світі. Ця турбота має стати першорядною за значущістю і починатися з моменту планування дитини.

У сучасному суспільстві відчуваються зміни що стосуються захисту життя людини. Діти шкільного віку, які характеризуються не лише віковими, психофізіологічними особливостями, а й специфікою соціального становлення, заслуговують на особливе місце в структурі суспільства. Вони потребують особливої уваги щодо створення сприятливих умов до їхнього життєвого самовизначення і самореалізації, у їхньому становленні як соціально-ціннісної, соціально-адаптивної, соціально-продуктивної особистості, успішної людини. Зазначено, що для того, аби забезпечити високий рівень професіоналізму майбутніх учителів початкових класів у конкретних умовах складного сучасного педагогічного процесу необхідна єдність теоретичної та практичної педагогічної підготовки.
\end{abstract}

Ключові слова: професійно-педагогічна підготовка, майбутні педагоги початкових класів, здоров'язбережувальні технології, педагогічна техніка, технологічна грамотність, педагогічна майстерність.

Постановка проблеми. Проблема формування, збереження, зміцнення й відновлення здоров’я дітей була, $є$ і завжди буде однією 3 головних у сучасній школі. Новітній навчальний заклад має будуватися на справжньому інтересі й повазі до дитини та надавати кожній дитині допомогу в пошуку власного життєвого шляху в суспільстві, у формуванні, закріпленні соціального досвіду, взаємодії, зберігаючи при цьому іiі фізичне та психофізичне здоров'я. А сама дитина має навчитись не лише писати, читати, рахувати, але й:

учитися берегти своє здоров'я;

знати орієнтири в нормальному стані людини;

вести здоровий спосіб життя;

активно займатися фізичною культурою;

дотримуватись гігієнічних норм;

(C) Потапчук T., 2020 
раціонально харчуватись;

загартовуватись;

уміти керувати своїми почуттями, настроєм, жити в гармонії з навколишнім середовищем;

усвідомлювати переваги підтримки свого організму в нормальному стані над жахливими наслідками шкідливих звичок (Терпелюк, 2011, с. 240-241).

Ці компоненти повинні бути складовими усього змісту освіти дитини в сім’ї, навчальному закладі, соціумі.

Аналіз останніх досліджень 3 проблеми. Залежність між станом учнівського здоров'я та рівнем підготовленості педагогів із питань його збереження i зміцнення детермінована якістю професійної підготовки майбутнього педагога до застосування здоров'язбережувальних технологій, що $є$ значущим фактором запобігання негативних впливів педагогічного процесу, розвитку здоров'я учнів через освіту (Білова В. (2007), Бойченко Т. (2008), Іваній І. (2008), Мешко Г. (2006), Рубан Н. (2010), Терпелюк В. (2011) та інші.

$\mathrm{У}$ наукових джерелах ефективність діяльності достатньо часто ототожнюється 3 поняттям продуктивності як характеристика діяльності, що відображає співвідношення між корисністю досягнутих за певний проміжок часу результатів і пов'язаними з цим витратами (Михно, 2014, с. 102-107).

Ефективність освіти відповідно до психолого-педагогічної довідникової літератури - це оціночна категорія, що характеризує результати освітньої діяльності за критерієм їх відповідності поставленим цілям (Кочерга. 2007, с. 14).

Отже, під ефективністю формування готовності студентів до використання здоров'язбережувальних технологій розуміють таку характеристику, що відображає співвідношення між метою формування та результатами, досягнутими у процесі здійснення.

Мета статті - теоретично обгрунтувати професійно-педагогічну підготовку майбутнього педагога початкових класів до використання здоров'язбережувальних технологій

Виклад основного матеріалу дослідження. Становлення i розвиток держави перед педагогічною системою особливо гостро висунуло проблему вдосконалення роботи педагогічних університетів щодо підготовки майбутніх педагогів початкових класів, які б мали високий рівень професіоналізму, творчої активності, відповідально ставилися до результатів свого навчання та підготовки до майбутньої професійної діяльності.

Оскільки система освіти має щоденний «доступ» до дитини, велика роль у підтримці здоров'я дитини належить учителю. Тому першочерговим завданням школи має бути збереження здоров'я дитини, за ним - високий рівень знань, а не навпаки. Система формування здоров'язбережувального середовища потребує постійного вдосконалення, і не останнє слово в цьому належить саме педагогам.

Педагоги-майстри, котрі мають глибокі знання з предмету, фундаментальну та психолого-педагогічну підготовку, високу загальну культуру, бажання формувати творчу особистість завжди потрібні у школі. Для того, щоб майбутні вчителі початкових класів могли реалізувати ці завдання, необхідно на ранніх етапах ознайомлювати їх з особливостями педагогічної діяльності в цілому, із сучасними вимогами до навчально-виховного процесу школи, який постійно розвивається.

Одним 3 найважливіших напрямів у професійно-педагогічній підготовці 
майбутніх педагогів початкових класів $\epsilon$ вдосконалення їх готовності до професійної діяльності в цілому та до впровадження здоров'язбережувальних технологій зокрема.

Саме в університеті у процесі навчання закладаються основи майбутньої педагогічної техніки, технологічної грамотності та педагогічної майстерності. Така готовність дає можливість молодому педагогу впевнено почувати себе в професійній діяльності, швидше адаптуватися в умовах сучасної школи, успішно виконувати складні завдання навчально-виховної роботи, вміти вивчати особистісні якості учнів, визначати оптимальні умови педагогічного впливу, глибоко аналізувати результати своєї діяльності (Мазін, 2007).

Для забезпечення високого рівня професіоналізму майбутніх учителів початкових класів у конкретних умовах складного сучасного педагогічного процесу необхідна єдність теоретичної та практичної педагогічної підготовки. На жаль, підготовка в університеті спрямована здебільшого на теоретичне осмислення суті навчально-виховного процесу загальноосвітньої школи, а формуванню комплексу професійно значущих якостей особистості не приділяється належна увага.

Готовність майбутнього вчителя початкових класів до професійної діяльності - це таке особистісне утворення, що забезпечує внутрішні умови для успішного виконання цієї діяльності. Компонентами готовності особистості до діяльності прийнято вважати ставлення до діяльності, мотиви, знання про предмет i способи діяльності, навики та вміння їхнього практичного використання. Насамперед необхідно виділити такі компоненти готовності, як мотиваційний, змістовий і операційний (Моніторинг, 2005).

Підготовка майбутніх вчителів початкових класів до формування в учнів здорового способу життя - це цілісна система, яка повинна відповідати вимогам суспільства, структурі і змісту освітньої підготовки сучасного вчителя. Компонентами цієї системи є мета, зміст, методи, засоби, форми, результати навчання. Тому метою підготовки майбутніх учителів початкових класів $\epsilon$ поглиблення знань про будову власного організму, розширення світогляду, усвідомлення зв'язку людини з довкіллям та ролі і місця ії в збереженні багатств i краси природи. Ця мета передбачає певні особливості в підготовці до впровадження здоров'язбережувальних технологій. Особливостями такої роботи $\epsilon$ актуалізація гуманістичного потенціалу майбутнього вчителя й трансформація педагогічної свідомості.

Процес підготовки майбутніх учителів початкових класів до здоров'язбережувальної діяльності прийнято розуміти як прояв індивідуальних можливостей, інтересів і здібностей студентів. Результатом цього $є$ фізично здорова особистість з багатим внутрішнім світом та розумінням сенсу життя, що адекватно реагує на різні життєві ситуації, вміє виражати свої почуття та емоції, володіє міцними соціально-економічними зв'язками та високим розвитком самовідчуття та самореалізації (Мешко, 2006, с. 17-21).

Побудова здоров'язбережувального навчально-виховного процессу вимагає від учителя достатнього рівня засвоєння професійних знань, наявності у нього цілого ряду компетенцій, що водночас є складовими його загальної культури та культури здоров'я зокрема.

Професійна компетентність педагога передбачає наявність професійних знань, умінь і навичок, забезпечення мобільності та поповнення професійних і особистісних якостей, гнучкість у засвоєнні методів теоретичної і способів 
практичної діяльності, критичність мислення, саморефлексія, прагнення до безперервного професійного росту. В іiі структурі важлива роль належить здоров'язберігаючій компетентності, що передбачає володіння відповідними теоретичними знаннями і навичками практичної діяльності. Реалізація ідеї здоров'язберігаючої педагогіки $є$ підставою для перебудови всієї роботи 3 урахуванням пріоритету збереження і зміцнення здоров'я дітей, яка втілюється в життя педагогічним колективом школи і кожним учителем окремо (Мешко, 2006, с. 17-21).

Учитель, володіючи сучасними педагогічними знаннями, при постійній взаємодії з учнями, їхніми батьками, медичними працівниками та психологом планує й організовує свою діяльність, ураховуючи пріоритети збереження та зміцнення здоров'я всіх суб'єктів педагогічного процесу. У своїй роботі він звертається до різноманітних педагогічних технологій.

У навчальному закладі найбільш доцільними є технології, які:

мають за основу комплексний характер збереження здоров’я;

беруть до уваги більшість чинників, що впливають на здоров'я;

враховують вікові та індивідуальні особливості учнів;

забезпечують запровадження мети й змісту політики освітнього закладу зі зміцнення здоров'я учнів та формування здорового способу життя;

контролюють виконання настанов, зміст яких має здоров'язбережувальний і профілактичний характер;

постійно покращують санітарно-гігієнічні умови навчального закладу, матеріально-технічну та навчальну базу, соціально-психологічний клімат у колективі відповідно до сучасних вимог;

заохочують учнів до участі в плануванні оздоровчої діяльності навчального закладу та до аналізу виконаної роботи;

формують позитивне ставлення учнів до навчального закладу, взаємоповагу та взаєморозуміння між учителями й учнями та учнів між собою;

обгрунтовують умови послідовності в реалізації технології;

здійснюють періодичну оцінку ефективності технології;

залучають батьків до збереження та зміцнення здоров'я дітей;

практикують особистісно зорієнтований стиль навчання та стосунків 3 учнями;

створюють освітнє середовище, що забезпечує комфортні та безпечні умови життєдіяльності учнів і вчителів (Рубан, 2010. с. 12-17).

Сутність здоров'язбережувальних та здоров'яформувальних технологій постає в комплексному оцінюванні умов виховання і навчання, які дають змогу зберігати наявний стан учнів, формувати більш високий рівень їхнього здоров'я, навичок здорового способу життя, здійснювати моніторинг показників індивідуального розвитку, прогнозувати можливі зміни здоров'я і проводити відповідні психолого - педагогічні, коригувальні, реабілітаційні заходи для забезпечення успішності навчальної діяльності та ії мінімальної фізіологічної «вартості», поліпшення якості життя суб'єктів освітнього середовища.

Знання, володіння й застосування здоров'язбережувальних технологій $\epsilon$ важливою складовою професійної компетентності сучасного педагога. Учителі в тісній взаємодії з учнями, батьками, медичними працівниками, практичними психологами, соціальними педагогами, усіма тими, хто зацікавлений у збереженні та зміцненні здоров'я дітей, спроможні створити здоров'язбережувальне освітнє середовище (Рубан, 2010. с. 12-17). 
Дослідженнями доведено, що ефективність формування здорового способу життя вимагає активного залучення учнів до здоров'язберігаючого навчального процесу, формування в них активної позиції щодо зміцнення і збереження власного здоров'я. Аналіз здоров'язберігаючої діяльності загальноосвітніх закладів України дозволив виділити складові моделі цієї діяльності. Вона має поєднувати такі форми і види роботи:

корекцію порушень соматичного здоров'я 3 використанням комплексу оздоровчих та медичних заходів без відриву від навчального процесу;

різноманітні форми організації навчально-виховного процесу з урахуванням ïx психологічного та фізіологічного впливу на учнів;

контроль за виконанням санітарно-гігієнічних норм організації навчальновиховного процесу; нормування навчального навантаження та профілактику перевтоми учнів;

медико-психолого-педагогічний моніторинг стану здоров'я, фізичного i психічного розвитку учнів;

розробку та реалізацію навчальних програм із формування в учнів навичок ведення здорового способу життя та профілактики шкідливих звичок;

діяльність служби психологічної допомога вчителям та учням у подоланні стресів, стану тривоги; сприяння гуманному ставленню до кожного учня; формування доброзичливих взаємовідносин у колективі вчителів;

організацію та контроль за дотриманням збалансованого харчування всіх учнів школи;

заходи, що сприяють збереженню і зміцненню здоров'я вчителів та учнів, створення умов для їх гармонійного розвитку (Іваній, Калініченко, 2008, с. 110117).

Висновки і перспективи подальших розвідок. Вирішення проблеми збереження здоров'я дітей потребує спільної увага всіх зацікавлених у цьому: педагогів, медиків, батьків, представників громадськості. Однак особливе місце та відповідальність щодо оздоровчої діяльності відводиться освітній системі, яка повинна й має всі можливості для того, щоб зробити освітній процес здоров'язберігаючим. У цій парадигмі мова йде вже не просто про стан здоров'я сучасних школярів, а про майбутнє України.

Велику увагу необхідно приділяти викладанню навчальних дисциплін, що базуються на здоров'язбережувальних технологіях та вивченні методик, що допомагають вчителю запровадити їх у навчальну діяльність. Здоров'язбережувальні технології вчать дітей жити без конфліктів, укріплювати, зберігати своє і цінувати чуже здоров'я. Ці технології прищеплюють дітям принципи здорового способу життя, посилюють мотивацію до навчання.

Очевидною $є$ потреба зміни ставлення до здоров'я дитини в системі освіти. Сьогодні урок як основна форма організації навчально-виховного процесу вже не вважається сучасним, навіть якщо він і вирізняється різноманіттям найсучасніших засобів та педагогічних прийомів, якщо під час його проведення дитина втрачає своє здоров'я. Це має бути заняття, яке викликає в учнів i вчителів задоволення, стимулює цікавість, творчість. Усе це досягається різноманітними формами роботи 3 використаннями інтерактивних та інноваційних технологій.

Отже, перед освітніми закладами все глобальніше постає завдання розроблення здоров'язбережувальних та здоров'яформувальних технологій, які б сприяли не лише максимальному розвиткові фізичного тіла учнів, а i їхньої 
психіки, вихованню духовності, виробленню навичок комунікативності. Тобто, формували здоров'я як багатоскладову категорію, у яку входить фізична, психічна, духовна й соціальна складові.

\section{СПИСОК ВИКОРИСТАНИХ ДЖЕРЕЛ}

Терпелюк, В. (2011). Формування основ здорового способу життя молодших школярів. Молода наука Волині: пріоритети та перспективи досліджень, 10-11 трав. 2011 р. М-во освіти і науки України, Волин. нац. ун-т ім. Лесі Українки, Наук. т-во студентів і аспірантів. Луцьк, Т. 1. С. 240-241.

Білова, В. (2007). 3 досвіду викладання фізичної культури в початковій школі. Фізичне виховання в школі. № 1. С. 32-35.

Бойченко, Т. (2008). Здоров'язберігаюча компетентність як ключова в освіті України. Основи здоров’я і фізична культура. № 11-12. С. 6-7.

Іваній, I. (2008). Ефективність змісту фізичного виховання особистісно орієнтованій технології розвитку основ здоров'я молодшого школяра. Ocвima $i$ здоров'я дітей : матеріали II Всеукр. наук.-практ. конф. $з$ міжнар. Участю. М-во освіти і науки України. Суми. С. 110-117.

Мешко, Г. (2006). Формування компетентності здоров'язбереження у майбутніх педагогів. Професійні компетениії та компетентності вчителя: Матер. регіон. наук.-практ. семінару. Тернопіль: ТНПУ ім. В. Гнатюка. С. 17-21.

Рубан, Н. (2010). Здоров'ятворчі та здоров'язбережувальні технології. Палітра педагога. № 2. С. 12-17.

Михно, Л. (2014). Здоров'яформуюча технологія фізичного виховання молодших школярів 3 використанням засобів йога-аеробіка. Спортивний вісник Придніпров'я. № 2. С. 102-107.

Кочерга, О. (2007). Психофізіологія навчання та здоров'я молодших школярів. Початкова школа. № 11. С. 1-4.

Мазін, В. (2007). Критерії та показники сформованості культури професійної самореалізації педагога. Педагогіка $i$ психологія формування творчої особистості: проблеми і пошуки. Вип. 41. С. 217-225.

Моніторинг і оцінка діяльності 3 формування здорового способу життя (2005). О. М. Балакірєва, О. О. Яременко, Р. Я. Левін та ін. К. : Укр. ін-т соц. досліджень, 152 с.

\section{REFERENCES}

Terpeliuk, V. (2011). Formuvannia osnov zdorovoho sposobu zhyttia molodshykh shkoliariv [Formation of healthy life of junior schoolchildren]. Moloda nauka Volyni: priorytety ta perspektyvy doslidzhen, 10-11 trav. 2011 r. M-vo osvity i nauky Ukrainy, Volyn. nats. un-t im. Lesi Ukrainky, Nauk. t-vo studentiv i aspirantiv. Lutsk, T. 1. S. 240-241. [in Ukrainian]

Bilova, V. (2007). Z dosvidu vykladannia fizychnoi kultury v pochatkovii shkoli [From the experience of teaching physical culture in primary school]. Fizychne vykhovannia $v$ shkoli. No 1. S. 32-35. [in Ukrainian]

Boichenko, T. (2008). Zdoroviazberihaiucha kompetentnist yak kliuchova v osviti Ukrainy [Health competence as a key in education in Ukraine]. Osnovy zdorovia $i$ fizychna kultura. No 11-12. S. 6-7. [in Ukrainian]

Ivanii, I. (2008). Efektyvnist zmistu fizychnoho vykhovannia osobystisno oriientovanii tekhnolohii rozvytku osnov zdorovia molodshoho shkoliara [The effectiveness of the content of physical education personality-oriented technology for 
the development of the health-life of primary school children ]. I. V. Ivanii, I. O. Kalinichenko. V: Osvita $i$ zdorovia ditei : materialy II Vseukr. nauk.-prakt. konf. z mizhnar. Uchastiu/ M-vo osvity i nauky Ukrainy. Sumy. S. 110-117. [in Ukrainian]

Meshko, H. (2006). Formuvannia kompetentnosti zdoroviazberezhennia u maibutnikh pedahohiv [Formation of health care competence in future teachers]. V: Profesiini kompetentsii ta kompetentnosti vchytelia: V: Mater. rehion. nauk.-prakt. seminaru. Ternopil: TNPU im. V. Hnatiuka, S. 17-21. [in Ukrainian]

Ruban, N. (2010). Zdoroviatvorchi ta zdoroviazberezhuvalni tekhnolohii [Health technologies] Palitra pedahoha. No 2. S. 12-17. [in Ukrainian]

Mykhno, L. (2014). Zdoroviaformuiucha tekhnolohiia fizychnoho vykhovannia molodshykh shkoliariv $\mathrm{z}$ vykorystanniam zasobiv yoha-aerobika [Health-forming technology of physical education of junior schoolchildren with the use of yogaaerobics]. Sportyvnyi visnyk Prydniprovia. No 2. S. 102-107. [in Ukrainian]

Kocherha, O. (2007). Psykhofiziolohiia navchannia ta zdorovia molodshykh shkoliariv [Psychophysiology of education and health of junior schoolchildren]. Pochatkova shkola. No 11. S. 1-4. [in Ukrainian]

Mazin, V. (2007). Kryterii ta pokaznyky sformovanosti kultury profesiinoi samorealizatsii pedahoha [Criteria and indicators of the formed culture of professional self-realization of teacher]. Pedahohika $i$ psykholohiia formuvannia tvorchoi osobystosti: problemy i poshuky. Vyp.41. S. 217-225. [in Ukrainian]

Monitorynh i otsinka diialnosti $\mathrm{z}$ formuvannia zdorovoho sposobu zhyttia [Monitoring and evaluation of activities for the formation of a healthy lifestyle]. O. Balakirieva, O. Yaremenko, R. Levin ta in.. K.: Ukr. in-t sots. Doslidzhen. 2005. 152 s. [in Ukrainian]

\title{
PROFESSIONAL AND PEDAGOGICAL TRAINING OF THE FUTURE TEACHER OF PRIMARY SCHOOL FOR USE OF HEALTH-LIFE TECHNOLOGIES
}

\author{
Tetiana Potapchuk \\ Doctor of Sciences (in Pedagogy), Professor, \\ Professor at the Department of Theory and \\ Methods of Preschool and Special Education, \\ SHEI "Vasyl Stefanyk Prykarpattia National University", \\ Ivano-Frankivsk, Ukraine \\ ORCID 0000-0003-1680-6976 \\ e-mail:tatvolod@ukr.net
}

\begin{abstract}
The article states that one of the important tasks of society is to take care of people, so human life and health is the main value of society. The state of health of the population is an important indicator of the development of society, so caring for human health, motivating it to a healthy lifestyle is given much attention around the world. This care should be paramount and begin with the planning of the child.

In modern society, attitude toward human life is changing. School-age children, who differ not only in age, psychophysiological features, but also in the specifics of social formation, deserve a special place in the structure of society.
\end{abstract}


They need special attention to creating favorable conditions for their life selfdetermination and self-realization, in their formation as a socially valuable, socially adaptive, socially productive personality, a successful person.

It is noted that in order to ensure a high level of professionalism of future primary school teachers in the specific conditions of a complex modern pedagogical process, the unity of theoretical and practical pedagogical training is necessary.

The essence of health-preserving and health-forming technologies is clarified, to predict possible changes in health and to carry out appropriate psychological pedagogical, corrective, rehabilitation measures to ensure the success of educational activities and its minimum physiological "value", to improve the quality of life of the subjects of the educational environment.

Key words: professional and pedagogical training, future primary school teachers, health-preserving technologies, pedagogical equipment, technological literacy, pedagogical skills.

Стаття надійшла до редакиії 10. 10. 2020 р. 